\title{
Standard climate models radiation codes underestimate black carbon radiative forcing
}

\author{
G. Myhre and B. H. Samset \\ Center for International Climate and Environmental Research - Oslo (CICERO), Oslo, Norway \\ Correspondence to: G. Myhre (gunnar.myhre@cicero.oslo.no)
}

Received: 29 August 2014 - Published in Atmos. Chem. Phys. Discuss.: 20 October 2014

Revised: 24 February 2015 - Accepted: 27 February 2015 - Published: 13 March 2015

\begin{abstract}
Radiative forcing (RF) of black carbon (BC) in the atmosphere is estimated using radiative transfer codes of various complexities. Here we show that the two-stream radiative transfer codes used most in climate models give too strong forward scattering, leading to enhanced absorption at the surface and too weak absorption by $\mathrm{BC}$ in the atmosphere. Such calculations are found to underestimate the positive RF of BC by $10 \%$ for global mean, all sky conditions, relative to the more sophisticated multi-stream models. The underestimation occurs primarily for low surface albedo, even though $\mathrm{BC}$ is more efficient for absorption of solar radiation over high surface albedo.
\end{abstract}

\section{Introduction}

Black carbon (BC) in the atmosphere has been investigated over many decades (Novakov and Rosen, 2013). The first estimate of radiative forcing (RF) of $\mathrm{BC}$ on a global scale was provided already 2 decades ago (Haywood and Shine, 1995). However, the diversity in existing estimates of the climate effect of BC is large (Bond et al., 2013; Boucher et al., 2013; Myhre et al., 2013). The causes for the diversity in estimates are many, from emissions (Amann et al., 2013; Cohen and Wang, 2014; Lam et al., 2012; Stohl et al., 2013; Wang et al., 2014b), lifetime and abundance (Hodnebrog et al., 2014; Samset et al., 2014; Wang et al., 2014a) to radiative efficiency (Samset et al., 2013; Zarzycki and Bond, 2010).

When estimating BC RF, the radiative transfer code is a crucial component. Accurate results can be achieved by using multi-stream line-by-line codes. However, these calculations are computationally demanding and are usually not applied for global scale simulations. In present climate mod- els, simplified radiation schemes of various complexity are therefore used and compared against line-by-line results, and each other, as consistency checks.

Several radiation intercomparison exercises have taken place (Boucher et al., 1998; Collins et al., 2006; Ellingson et al., 1991; Forster et al., 2011, 2005; Myhre et al., 2009b; Randles et al., 2013), yielding important suggestions for improvement to the radiative transfer codes. Randles et al. (2013) found that many of the presently used radiative transfer codes underestimate the radiative effect of absorbing aerosols, relative to benchmark multi-stream lineby-line codes. Further, one of the radiative transfer codes was run both as a multi-stream code resembling the benchmark codes, as well as run as a two-stream code resembling the simpler codes used in climate models. These two codes were denoted as numbers 3 and 4, respectively in Randles et al. (2013) and used in the current work. The results indicated that the number of streams in the radiative transfer calculation, i.e. the number of angles through which radiation is allowed to scatter, is crucial for the differences found between the radiation codes. On average, the simpler codes underestimated the radiative effect of $\mathrm{BC}$ of the order of $10-15 \%$ relative to the benchmark line-by-line codes. In the present study we further investigate this potential underestimation of BC RF in many of the global climate models, and develop a physical understanding for why it occurs.

\section{Models and methods}

Simulations in the present paper were performed with a radiative transfer code using the discrete ordinate method (Stamnes et al., 1988). This model has previously been run in idealized experiments with prescribed vertical profiles 
of aerosol extinction (Randles et al., 2013) and used for global climate simulations (Myhre et al., 2009a). The radiative transfer code was run either in a multi-stream mode (eight streams) or with two streams and the Delta-M method (Wiscombe, 1977). In the global simulations we used meteorological data from ECMWF, and specified aerosol optical properties (Myhre et al., 2009a) and aerosol distribution from the OsloCTM2 chemical transport model (Skeie et al., 2011). To study the impact of the radiation code on global mean RF of $\mathrm{BC}$, input fields and results from OsloCTM2 part of AeroCom Phase II for several aerosol components were used. Here, aerosol BC abundances were specified for 1850 and 2000, and anthropogenic RF defined as the difference between outgoing top-of-atmosphere shortwave radiative flux between these 2 years (Myhre et al., 2013).

\section{Results}

\subsection{Global distribution of underestimated BC RF in models}

Figure 1a shows the global mean, clear sky direct effect RF of $\mathrm{BC}$, for a two-stream simulation relative to a simulation with eight streams. As in Randles et al. (2013) we find that the two-stream calculation tends to give lower RF than the eightstream one. The underestimation in the two-stream simulation is shown here to be largest over ocean, with low surface albedo, whereas over regions with high surface albedo the two-stream more closely reproduces the eight-stream simulation. Under clear sky conditions, the global, annual mean underestimation is $15 \%\left(0.158\right.$ vs. $\left.0.187 \mathrm{~W} \mathrm{~m}^{-2}\right)$ in the twostream relative to eight-stream simulation ( $\mathrm{RF}$ (two-stream) divided by RF (eight-stream)).

The albedo of clouds is also affected by the number of streams adopted in the radiative transfer simulations. This makes the top-of-atmosphere reflected solar radiation increase in two-stream calculations, relative to eight-stream simulations. For all sky conditions, the global mean underestimation of RF in the two-stream simulation amounts to $7 \%$. However, modifying the cloud scattering to get similar topof-atmosphere solar flux, as in the eight-stream simulation and close to measured fluxes, leads to a $10 \%$ underestimation in the two-stream simulation relative to the eight-stream simulation $\left(0.254\right.$ vs. $\left.0.283 \mathrm{~W} \mathrm{~m}^{-2}\right)$. The largest underestimation is over ocean, and over regions with small cloud cover, as shown in Fig. $1 b$.

\subsection{Underestimation of BC RF as a function of altitude}

Global mean RF of BC, as a function of BC located at various altitudes, is shown in Fig. 2. The figure shows results for both two-stream and eight-stream simulations. A similar curve has previously been presented in Samset and Myhre (2011) for eight-stream simulations. The present curve is slightly modified, due to updated ozone and cloud fields. The same ap-
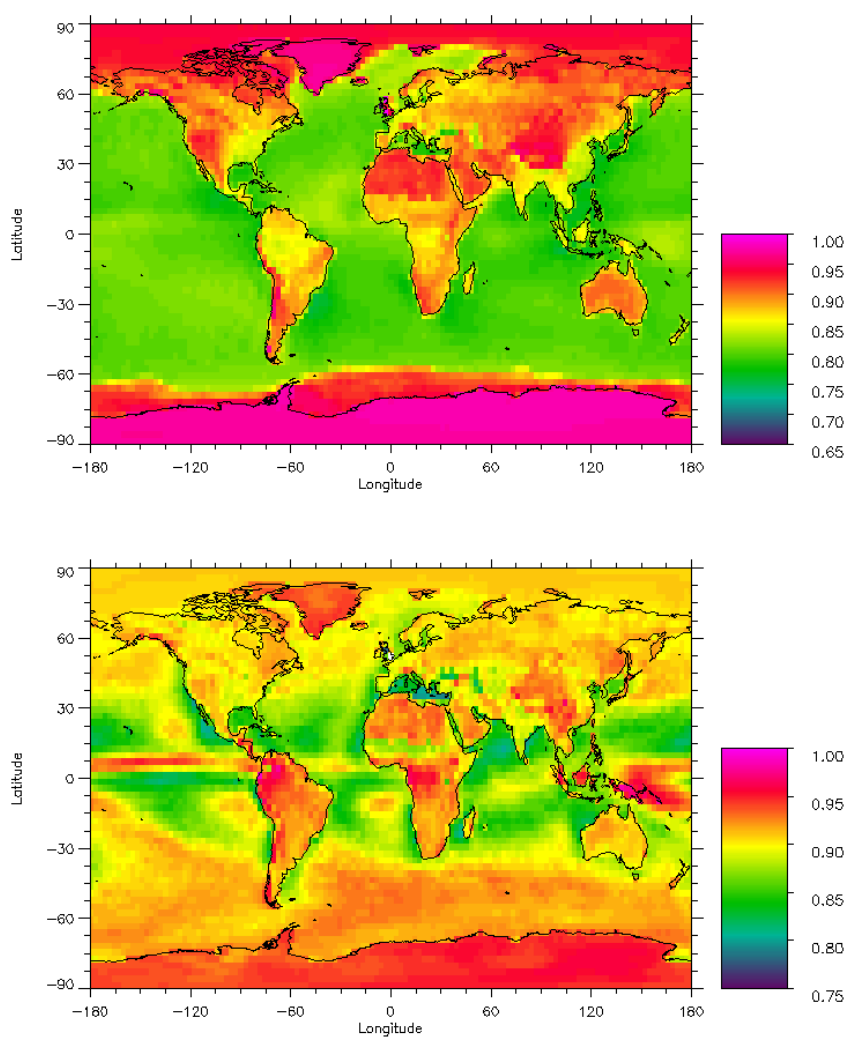

Figure 1. Geographical distribution of ratio between annual mean $\mathrm{RF}$ of BC from two-stream simulation relative to eight-stream simulation for clear sky (upper) and all sky (lower).

proach as in Sect. 3.1, to keep cloud scattering and therefore top-of-atmosphere radiative flux for the two-stream simulation equal to the eight-stream simulation, has been applied.

Figure $2 \mathrm{a}$ clearly shows the increasing normalized RF (RF exerted per unit aerosol burden) by $\mathrm{BC}$ as a function of altitude, due to enhanced effect of absorbing material above scattering components. The underestimation in the two-stream simulation is similar in magnitude for clear sky and all sky conditions, but is, in relative terms, larger for clear sky due to smaller absolute values (Fig. 2b).

For the all sky simulation the underestimation by the twostream vs. the eight-stream simulation is close to $10 \%$ for BC at all altitudes, except below $900 \mathrm{hPa}$. Being above scattering components such as clouds increases the absorption by BC, as does the presence of scattering aerosol types, and Rayleigh scattering. Absorption by gases such as ozone and water vapour, as well as absorption by other aerosol types, reduces the absorption by BC. For all sky conditions, Fig. 2 shows a large degree of compensation by scattering and absorption by gases, and other aerosol types than BC. In a model simulation with only $\mathrm{BC}$ in the atmosphere, the normalized $\mathrm{RF}$ of $\mathrm{BC}$ was found to be $1 \%$ higher in two-stream simulations than in eight-stream simulations, showing the importance of 

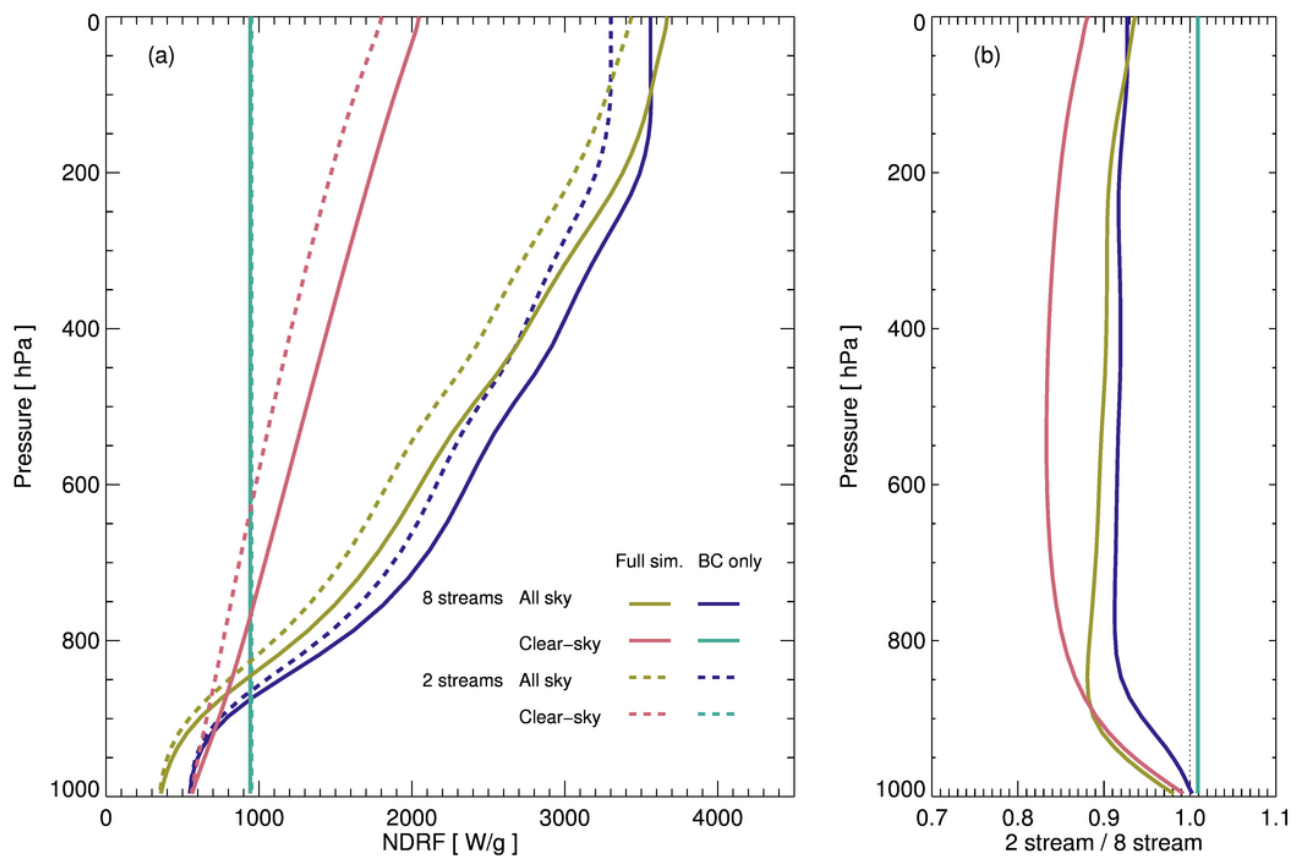

Figure 2. (a) BC RF normalized by abundance, as a function of altitude. Solid lines: eight-stream simulations. Dashed lines: two-stream simulations. Colours represent all sky and clear sky conditions, and whether a full atmospheric simulation including Rayleigh scattering, water vapour and background aerosols was performed ("Full sim"), or if BC was the only radiatively active agent ("BC only"); (b) ratio of two-stream to eight-stream simulation results, for the four cases shown in (a).

the other atmospheric components for the correct determination of BC RF.

\subsection{Physical description of the underestimation of $\mathrm{BC}$ RF}

The radiative forcing due to aerosols is known to be a strong function of surface albedo (Haywood and Shine, 1997). This is illustrated in Fig. 3a, where the radiative effect of aerosols with different single scattering albedo has been calculated as a function of surface albedo. We reproduce the well-known characteristics of largest impact of absorbing aerosols over bright surfaces, and of scattering aerosols over dark surfaces.

Figure $3 \mathrm{~b}$ shows the difference between two-stream and eight-stream calculations, as a function of surface albedo, and for a range of aerosol single scattering albedos. Twostream and eight-stream results deviate substantially between surface albedos of 0.05 and 0.2 . These are surface albedo values where absorbing aerosols have a relatively weak radiative effect. An increasing single scattering albedo gives increasing underestimations of two-stream results (Fig. 3b) and at the same time a decreasing radiative effect (Fig. 3a).

Our interpretation of the cause for the underestimation of two-stream results relative to multi-stream (containing more than two streams) results is lack of sufficient multiple scattering in connection to forward scattering and low surface albedo. Under such conditions the scattering is too strong in the forward direction in two-stream approaches. In addi- tion the low surface albedo, and thus strong surface absorption, hinders further multiple scattering. Multiple scattering in general enhances the radiative effect of absorbing aerosols.

To illustrate the importance of multiple scattering for the abovementioned underestimation, additional simulations show that purely absorbing aerosols in a non-scattering atmosphere have differences between two-stream and multistream results within only a few percent (less than $2 \%$ ), which is the typical deviation as shown in Figure 3b, except for at low surface albedo. The agreement between 8stream and even higher number of streams such as 16-stream simulations is generally within $1 \%$, except for very small absolute RF values. Simulations with four streams are generally close to eight-stream simulations. For pure scattering aerosols, two-stream simulations vary with solar zenith angle (see Randles et al., 2013) and surface albedo compared to eight-stream simulations; on a global mean, negative RF for anthropogenic sulphate aerosols is $5 \%$ stronger. The results shown in Fig. 3 are for a solar zenith angle of $30^{\circ}$, but are generally applicable for other solar zenith angles. However, note that the critical single scattering albedo for transitioning from positive to negative radiative effect decreases with increasing solar zenith angle. The underestimation shown in Randles et al. (2013) can also be seen in Figure $3 \mathrm{~b}$ for a single scattering of 0.75 (close to 0.8 used in the paper) and for a surface albedo of 0.2 at around $10 \%$. 

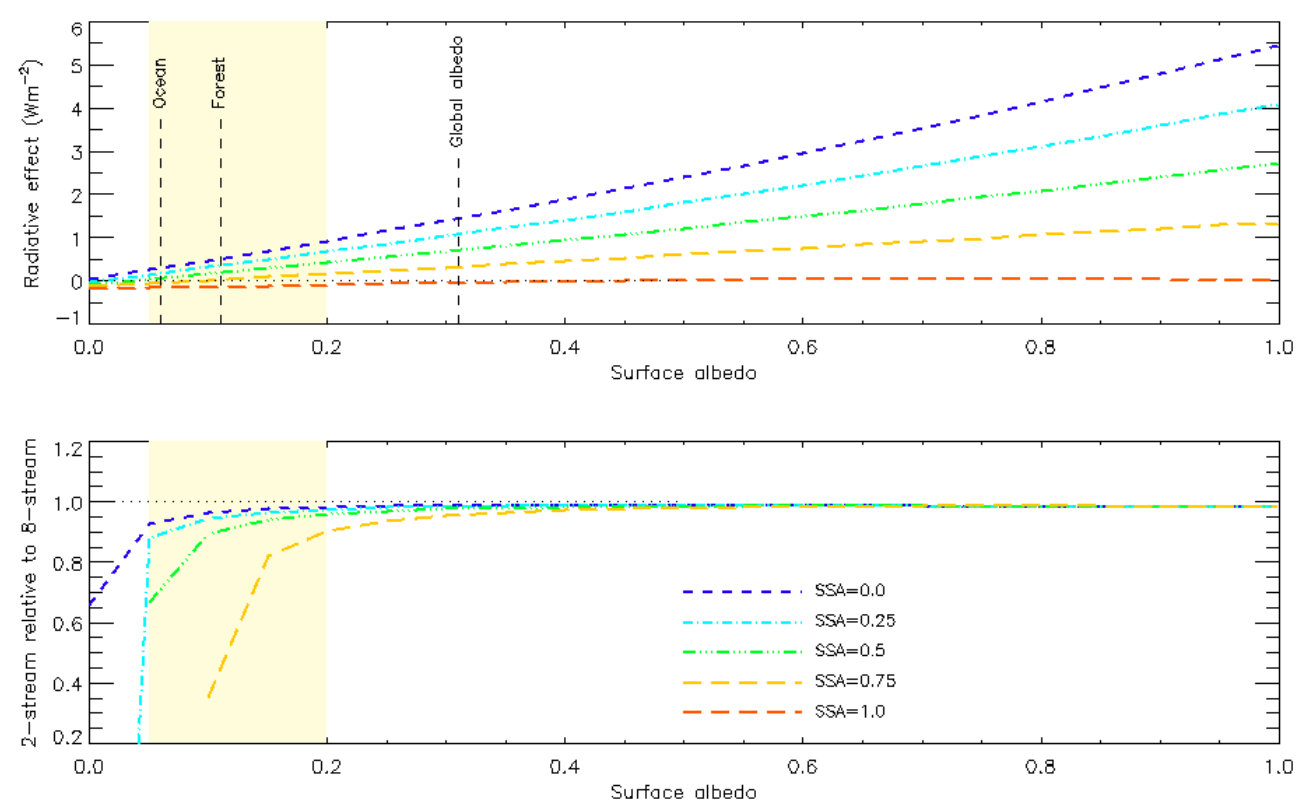

Figure 3. RF as a function of surface albedo for various single scattering albedo (upper), and relative differences between two-stream and multi-stream simulations (lower). In cases where the sign of two-stream and multi-stream simulations for a particular single-scattering albedo differs the results are left out of the lower panel.

\section{Conclusions}

Two-stream approximations using the Delta-M method, as employed by a majority of present climate models, are found to be relatively accurate for absorbing aerosols. The exception is over areas with low surface albedo. Here, the enhanced forward scattering hinders sufficient multiple scattering, causing an underestimation of the radiative effect of BC. Low albedo occurs in regions with low cloud cover, and low surface albedo such as ocean and snow free forest. In such cases the underestimation relative to more advanced radiation schemes can be of the order of $20-25 \%$. The underestimation for $\mathrm{BC}$ is largest in the presence of scattering components. This also applies to gases with solar absorption. However, under clear sky condition, underestimation of a similar magnitude to BC will only be caused by gases with solar absorption in UV and visible region where Rayleigh scattering is strong. Thus ozone in the lower troposphere is the only gas that is substantially influenced by the number of streams in the radiative transfer simulations. For a global increase in water vapour by $20 \%$ in the lowest $1-2 \mathrm{~km}$ of the atmosphere, the difference between two-stream and eight-stream simulations is found to be less than $1 \%$.

On a global scale, we simulate a $10 \%$ underestimation for $\mathrm{RF}$ of $\mathrm{BC}$ for all sky conditions, and $15 \%$ for clear sky, for two-stream relative to eight-stream simulations. The clear sky results for selected profiles and solar zenith angles in Randles et al. (2013) showed an average model underestimation between 12 and $15 \%$ compared to benchmark model simulations. The implication of the underestimation is that recent estimates of global mean RF due to BC, e.g., in Myhre et al. (2013) and Bond et al. (2013), where the latter is based on radiative transfer calculations in Schulz et al. (2006), could be up to $10 \%$ too weak, as they are primarily based on models with radiative transfer codes with two-stream simulations. It must however be noted that other issues related to radiative transfer codes may lead to compensation of this underestimation, or additional underestimation. In addition, uncertainties in the abundance of $\mathrm{BC}$, and in its optical properties, are much larger than $10 \%$. Burden of $\mathrm{BC}$ and the normalized RF has a standard deviation of the order of $50 \%$ relative to mean values for the 15 global aerosol models in AeroCom Phase II (Myhre et al., 2013). Even so, considerations for improvements of radiation schemes in global climate models should be made to provide more accurate calculations of present and future radiative forcing due to BC.

Acknowledgements. This work has received funding from the European Union Seventh Framework Programme (FP7/2007-2013) under grant agreement no. 282688 - ECLIPSE as well as from the Research Council of Norway through the projects EarthClim, AEROCOM-P3, and SLAC.

Edited by: Y. Balkanski 


\section{References}

Amann, M., Klimont, Z., and Wagner, F.: Regional and Global Emissions of Air Pollutants: Recent Trends and Future Scenarios, in: Annual Review of Environment and Resources, Vol. 38, Annual Review of Environment and Resources, edited by: Gadgil, A. and Liverman, D. M., 31-55, 2013.

Bond, T. C., Doherty, S. J., Fahey, D. W., Forster, P. M., Berntsen, T., DeAngelo, B. J., Flanner, M. G., Ghan, S., Karcher, B., Koch, D., Kinne, S., Kondo, Y., Quinn, P. K., Sarofim, M. C., Schultz, M. G., Schulz, M., Venkataraman, C., Zhang, H., Zhang, S., Bellouin, N., Guttikunda, S. K., Hopke, P. K., Jacobson, M. Z., Kaiser, J. W., Klimont, Z., Lohmann, U., Schwarz, J. P., Shindell, D., Storelvmo, T., Warren, S. G., and Zender, C. S.: Bounding the role of black carbon in the climate system: A scientific assessment, J. Geophys. Res.-Atmos., 118, 5380-5552, 2013.

Boucher, O., Schwartz, S. E., Ackerman, T. P., Anderson, T. L., Bergstrom, B., Bonnel, B., Chylek, P., Dahlback, A., Fouquart, Y., Fu, Q., Halthore, R. N., Haywood, J. M., Iversen, T., Kato, S., Kinne, S., Kirkevag, A., Knapp, K. R., Lacis, A., Laszlo, I., Mishchenko, M. I., Nemesure, S., Ramaswamy, V., Roberts, D. L., Russell, P., Schlesinger, M. E., Stephens, G. L., Wagener, R., Wang, M., Wong, J., and Yang, F.: Intercomparison of models representing direct shortwave radiative forcing by sulfate aerosols, J. Geophys. Res.-Atmos., 103, 16979-16998, 1998.

Boucher, O., Randall, D., Artaxo, P., Bretherton, C., Feingold, G., Forster, P., Kerminen, V.-M., Kondo, Y., Liao, H., Lohmann, U., Rasch, P., Satheesh, S. K., Sherwood, S., Stevens, B., and Zhang, X.-Y.: Clouds and Aerosols, in: Climate Change 2013: The Physical Science Basis. Contribution of Working Group I to the Fifth Assessment Report of the Intergovernmental Panel on Climate Change, edited by: Stocker, T. F., Qin, D., Plattner, G.-K., Tignor, M., Allen, S. K., Boschung, J., Nauels, A., Xia, Y., Bex, V., Midgley, P. M., Cambridge University Press, Cambridge, United Kingdom and New York, NY, USA, 571-657, 2013.

Cohen, J. B. and Wang, C.: Estimating global black carbon emissions using a top-down Kalman Filter approach, J. Geophys. Res.-Atmos., 119, 307-323, 2014.

Collins, W. D., Ramaswamy, V., Schwarzkopf, M. D., Sun, Y., Portmann, R. W., Fu, Q., Casanova, S. E. B., Dufresne, J. L., Fillmore, D. W., Forster, P. M. D., Galin, V. Y., Gohar, L. K., Ingram, W. J., Kratz, D. P., Lefebvre, M. P., Li, J., Marquet, P., Oinas, V., Tsushima, Y., Uchiyama, T., and Zhong, W. Y.: Radiative forcing by well-mixed greenhouse gases: Estimates from climate models in the Intergovernmental Panel on Climate Change (IPCC) Fourth Assessment Report (AR4), J. Geophys. Res.-Atmos., 111, D14317, doi:10.1029/2005JD006713, 2006.

Ellingson, R. G., Ellis, J., and Fels, S.: The intercomparison of radiation codes used in climate models - long-wave results, J. Geophys. Res.-Atmos., 96, 8929-8953, 1991.

Forster, P. M. D., Burkholder, J. B., Clerbaux, C., Coheur, P. F., Dutta, M., Gohar, L. K., Hurley, M. D., Myhre, G., Portmann, R. W., Shine, K. P., Wallington, T. J., and Wuebbles, D.: Resolution of the uncertainties in the radiative forcing of HFC-134a, J. Quant. Spectrosc. Ra., 93, 447-460, 2005.

Forster, P. M. D., Fomichev, V. I., Rozanov, E., Cagnazzo, C., Jonsson, A. I., Langematz, U., Fomin, B., Iacono, M. J., Mayer, B., Mlawer, E., Myhre, G., Portmann, R. W., Akiyoshi, H., Falaleeva, V., Gillett, N., Karpechko, A., Li, J. N., Lemennais, P., Morgenstern, O., Oberlander, S., Sigmond, M., and Shibata,
K.: Evaluation of radiation scheme performance within chemistry climate models, J. Geophys. Res.-Atmos., 116, D10302, doi:10.1029/2010JD015361, 2011.

Haywood, J. M. and Shine, K. P.: The effect of anthropogenic sulfate and soot aerosol on the clear-sky planetary radiation budget, Geophys. Res. Lett., 22, 603-606, 1995.

Haywood, J. M. and Shine, K. P.: Multi-spectral calculations of the direct radiative forcing of tropospheric sulphate and soot aerosols using a column model, Q. J. Roy. Meteor. Soc., 123, 1907-1930, 1997.

Hodnebrog, Ø., Myhre, G., and Samset, B. H.: How shorter black carbon lifetime alters its climate effect, Nat. Commun., 5, 5065, doi:10.1038/ncomms6065, 2014.

Lam, N. L., Chen, Y., Weyant, C., Venkataraman, C., Sadavarte, P., Johnson, M. A., Smith, K. R., Brem, B. T., Arineitwe, J., Ellis, J. E., and Bond, T. C.: Household Light Makes Global Heat: High Black Carbon Emissions From Kerosene Wick Lamps, Environ. Sci. Technol., 46, 13531-13538, 2012.

Myhre, G., Berglen, T. F., Johnsrud, M., Hoyle, C. R., Berntsen, T. K., Christopher, S. A., Fahey, D. W., Isaksen, I. S. A., Jones, T. A., Kahn, R. A., Loeb, N., Quinn, P., Remer, L., Schwarz, J. P., and Yttri, K. E.: Modelled radiative forcing of the direct aerosol effect with multi-observation evaluation, Atmos. Chem. Phys., 9, 1365-1392, doi:10.5194/acp-9-1365-2009, 2009a.

Myhre, G., Kvalevag, M., Radel, G., Cook, J., Shine, K. P., Clark, H., Karcher, F., Markowicz, K., Kardas, A., Wolkenberg, P., Balkanski, Y., Ponater, M., Forster, P., Rap, A., and de Leon, R. R.: Intercomparison of radiative forcing calculations of stratospheric water vapour and contrails, Meteorol. Z., 18, 585-596, 2009b.

Myhre, G., Samset, B. H., Schulz, M., Balkanski, Y., Bauer, S., Berntsen, T. K., Bian, H., Bellouin, N., Chin, M., Diehl, T., Easter, R. C., Feichter, J., Ghan, S. J., Hauglustaine, D., Iversen, T., Kinne, S., Kirkevåg, A., Lamarque, J.-F., Lin, G., Liu, X., Lund, M. T., Luo, G., Ma, X., van Noije, T., Penner, J. E., Rasch, P. J., Ruiz, A., Seland, Ø., Skeie, R. B., Stier, P., Takemura, T., Tsigaridis, K., Wang, P., Wang, Z., Xu, L., Yu, H., Yu, F., Yoon, J.-H., Zhang, K., Zhang, H., and Zhou, C.: Radiative forcing of the direct aerosol effect from AeroCom Phase II simulations, Atmos. Chem. Phys., 13, 1853-1877, doi:10.5194/acp-13-18532013, 2013.

Novakov, T. and Rosen, H.: The Black Carbon Story: Early History and New Perspectives, Ambio, 42, 840-851, 2013.

Randles, C. A., Kinne, S., Myhre, G., Schulz, M., Stier, P., Fischer, J., Doppler, L., Highwood, E., Ryder, C., Harris, B., Huttunen, J., Ma, Y., Pinker, R. T., Mayer, B., Neubauer, D., Hitzenberger, R., Oreopoulos, L., Lee, D., Pitari, G., Di Genova, G., Quaas, J., Rose, F. G., Kato, S., Rumbold, S. T., Vardavas, I., Hatzianastassiou, N., Matsoukas, C., Yu, H., Zhang, F., Zhang, H., and $\mathrm{Lu}$, P.: Intercomparison of shortwave radiative transfer schemes in global aerosol modeling: results from the AeroCom Radiative Transfer Experiment, Atmos. Chem. Phys., 13, 2347-2379, doi:10.5194/acp-13-2347-2013, 2013.

Samset, B. H. and Myhre, G.: Vertical dependence of black carbon, sulphate and biomass burning aerosol radiative forcing, Geophys. Res. Lett., 38, L24802, doi:10.1029/2011g1049697, 2011.

Samset, B. H., Myhre, G., Schulz, M., Balkanski, Y., Bauer, S., Berntsen, T. K., Bian, H., Bellouin, N., Diehl, T., Easter, R. C., Ghan, S. J., Iversen, T., Kinne, S., Kirkevåg, A., Lamarque, J.- 
F., Lin, G., Liu, X., Penner, J. E., Seland, Ø., Skeie, R. B., Stier, P., Takemura, T., Tsigaridis, K., and Zhang, K.: Black carbon vertical profiles strongly affect its radiative forcing uncertainty, Atmos. Chem. Phys., 13, 2423-2434, doi:10.5194/acp-13-24232013, 2013.

Samset, B. H., Myhre, G., Herber, A., Kondo, Y., Li, S.-M., Moteki, N., Koike, M., Oshima, N., Schwarz, J. P., Balkanski, Y., Bauer, S. E., Bellouin, N., Berntsen, T. K., Bian, H., Chin, M., Diehl, T., Easter, R. C., Ghan, S. J., Iversen, T., Kirkevåg, A., Lamarque, J.-F., Lin, G., Liu, X., Penner, J. E., Schulz, M., Seland, Ø., Skeie, R. B., Stier, P., Takemura, T., Tsigaridis, K., and Zhang, K.: Modelled black carbon radiative forcing and atmospheric lifetime in AeroCom Phase II constrained by aircraft observations, Atmos. Chem. Phys., 14, 12465-12477, doi:10.5194/acp14-12465-2014, 2014.

Schulz, M., Textor, C., Kinne, S., Balkanski, Y., Bauer, S., Berntsen, T., Berglen, T., Boucher, O., Dentener, F., Guibert, S., Isaksen, I. S. A., Iversen, T., Koch, D., Kirkevåg, A., Liu, X., Montanaro, V., Myhre, G., Penner, J. E., Pitari, G., Reddy, S., Seland, $\varnothing .$, Stier, P., and Takemura, T.: Radiative forcing by aerosols as derived from the AeroCom present-day and pre-industrial simulations, Atmos. Chem. Phys., 6, 5225-5246, doi:10.5194/acp-65225-2006, 2006.

Skeie, R. B., Berntsen, T. K., Myhre, G., Tanaka, K., Kvalevåg, M. M., and Hoyle, C. R.: Anthropogenic radiative forcing time series from pre-industrial times until 2010, Atmos. Chem. Phys., 11, 11827-11857, doi:10.5194/acp-11-11827-2011, 2011.
Stamnes, K., Tsay, S. C., Wiscombe, W., and Jayaweera, K.: Numerically Stable Algorithm For Discrete-Ordinate-Method Radiative-Transfer In Multiple-Scattering And Emitting Layered Media, Appl. Optics, 27, 2502-2509, 1988.

Stohl, A., Klimont, Z., Eckhardt, S., Kupiainen, K., Shevchenko, V. P., Kopeikin, V. M., and Novigatsky, A. N.: Black carbon in the Arctic: the underestimated role of gas flaring and residential combustion emissions, Atmos. Chem. Phys., 13, 8833-8855, doi:10.5194/acp-13-8833-2013, 2013.

Wang, Q. Q., Jacob, D. J., Spackman, J. R., Perring, A. E., Schwarz, J. P., Moteki, N., Marais, E. A., Ge, C., Wang, J., and Barrett, S. R. H.: Global budget and radiative forcing of black carbon aerosol: Constraints from pole-to-pole (HIPPO) observations across the Pacific, J. Geophys. Res.-Atmos., 119, 195-206, 2014a.

Wang, R., Tao, S., Balkanski, Y., Ciais, P., Boucher, O., Liu, J. F., Piao, S. L., Shen, H. Z., Vuolo, M. R., Valari, M., Chen, H., Chen, Y. C., Cozic, A., Huang, Y., Li, B. G., Li, W., Shen, G. F., Wang, B., and Zhang, Y. Y.: Exposure to ambient black carbon derived from a unique inventory and high-resolution model, P. Natl. Acad. Sci. USA, 111, 2459-2463, 2014b.

Wiscombe, W. J.: Delta-M method - rapid yet accurate radiative flux calculations for strongly asymmetric phase functions, J. Atmos. Sci., 34, 1408-1422, 1977.

Zarzycki, C. M. and Bond, T. C.: How much can the vertical distribution of black carbon affect its global direct radiative forcing?, Geophys. Res. Lett., 37, L20807, doi:10.1029/2010g1044555, 2010. 